\title{
Comparative structural analysis of retroviral fusion proteins identifies regions that modulate membrane fusion: a potential retroviral achilles heal?
}

\author{
Daniel Lamb ${ }^{1}$, Alexander W Schüttelkopf ${ }^{2}$, Daan M F van Aalten², David W Brighty ${ }^{1 *}$ \\ From 15th International Conference on Human Retroviruses: HTLV and Related Viruses \\ Leuven and Gembloux, Belgium. 5-8 June 2011
}

Refolding of viral class-1 membrane fusion proteins from a native state to a trimer-of-hairpins structure promotes entry of viruses into cells. Here we present the structure of the bovine leukaemia virus transmembrane glycoprotein (TM) and identify a group of asparagine residues at the membrane-distal end of the trimer of hairpins that is strikingly conserved among divergent viruses. These asparagines are not essential for surface display of pre-fusogenic envelope. Instead, substitution of these residues dramatically disrupts membrane fusion. Our data indicate that through electrostatic interactions with of a chloride ion the asparagine residues promote assembly and profoundly stabilize the fusion-active structures that are required for viral envelope-mediated membrane fusion. Moreover, the BLV TM structure also reveals a charge-surrounded hydrophobic pocket on the central coiled coil and interactions with basic residues that cluster around this pocket are critical to membrane fusion and form a target for peptide inhibitors of envelope function. Charge-surrounded pockets and electrostatic interactions with small ions are common leitmotifs among class-1 fusion proteins. We will discuss the impact of these observations in light of current models of membrane fusion and as potential targets for therapeutic inhibition of viral entry.

\section{Author details}

'The Biomedical Research Institute, College of Medicine, Ninewells Hospital, University, Dundee, Scotland, DD1 9SY, UK. ${ }^{2}$ Division of Molecular

\footnotetext{
* Correspondence: d.w.brighty@dundee.ac.uk

'The Biomedical Research Institute, College of Medicine, Ninewells Hospital, University, Dundee, Scotland, DD1 9SY, UK

Full list of author information is available at the end of the article
}

Microbiology, College of Life Sciences, University of Dundee, Dundee, DD1 5EH2, UK.

Published: 6 June 2011

doi:10.1186/1742-4690-8-S1-A163

Cite this article as: Lamb et al:: Comparative structural analysis of retroviral fusion proteins identifies regions that modulate membrane fusion: a potential retroviral achilles heal? Retrovirology 2011 8(Suppl 1): A163.
Submit your next manuscript to BioMed Central and take full advantage of:

- Convenient online submission

- Thorough peer review

- No space constraints or color figure charges

- Immediate publication on acceptance

- Inclusion in PubMed, CAS, Scopus and Google Scholar

- Research which is freely available for redistribution

Submit your manuscript at www.biomedcentral.com/submit
() Biomed Central 